\section{Penggunaan Media Teknologi Informasi dalam Pembelajaran Pendidikan Agama Kristen di Masa Pandemi Covid-19}

\author{
Hermanto Sihotang \\ Sekolah Tinggi Teologi Sumatera Utara \\ sihotanghermanto@gmail.com
}

\begin{abstract}
Christian religious education has a strategic role in the inheritance of the values of Christian life and faith as taught by the Bible, the Word of God, which can take place in families, churches and schools. There are complaints related to the lack of interest in learning PAK by students. So to overcome this the teacher must apply a variety of learning strategies including those that allow the use of information technology media in it. In addition, the covid-19 phenomenon is a new challenge, especially in the world of education - learning that cannot be done face-to-face. Teachers must optimize their insights and skills in information technology to be able to answer challenges. Parents should create a good climate at home and facilitate children's learning facilities. In this paper, descriptive qualitative methods or library research are used to obtain and analyze data regarding the use of information technology in the learning process of Christian religious education during the pandemic. The findings obtained are that the use of information technology in Christian religious education has basically become a demand for Christian religious education teachers, especially in the era of disruption. During the Covid-19 pandemic, these demands were far different, and made Christian religious education teachers even more motivated and inevitably had to adjust to online learning, master and apply this educational technology so that in the end it resulted in learning Christian religious education in schools.
\end{abstract}

Keywords: Christian religious education; information technology; internet; pandemic covid-19

Abstrak: Pendidikan agama Kristen memiliki peran yang strategis dalam pewarisan nilai-nilai hidup dan iman kristiani sebagaimana yang diajarkan Alkitab, Firman Allah, yang dapat berlangsung di keluarga, gereja dan sekolah. Adanya keluhan terkait kurangnya minat belajar PAK oleh peserta didik. Maka untuk mengatasi hal tersebut guru harus menerapkan strategi pembelajaran yang variatif termasuk yang memungkinkan penggunaan media teknologi informasi di dalamnya. Disamping itu, fenomena covid-19 menjadi tantangan baru, khususnya dalam dunia pendidikan - pembelajaran yang tidak bisa dilakukan dengan tatap muka. Guru harus mengoptimalkan wawasan dan keterampilannya dalam hal teknologi informasi untuk dapat menjawab tantangan. Orang tua hendaknya menciptakan iklim yang baik di rumah dan memfasilitasi sarana belajar anak. Dalam tulisan ini digunakan metode kualitatif deskriptif atau studi pustaka (library research) untuk memperoleh dan menganalisis data berkenaan dengan penggunaan teknologi informasi dalam proses pembelajaran pendidikan agama Kristen di masa pandemi. Hasil temuan yang diperoleh adalah bahwa pemanfaatan teknologi informasi dalam pendidikan agama Kristen pada dasarnya sudah menjadi tuntutan bagi guru-guru pendidikan agama Kristen, khususnya di era disrupsi. Di masa pandemi covid-19 tuntutan tersebut jauh berbeda, dan membuat guru-guru pendidikan agama Kristen semakin terpacu dan mau tidak mau harus menyesuaikan diri dengan pembelajaran daring, menguasai dan menerapkan teknologi pendidikan tersebut sehingga pada akhirnya memberhasilkan belajar pendidikan agama Kristen di sekolah.

Kata kunci: pendidikan agama Kristen; teknologi informasi; internet; pandemi covid-19 


\section{Pendahuluan}

Teknologi informasi telah mengubah wajah pembelajaran yang berbeda dengan proses pembelajaran tradisional yang ditandai dengan interaksi tatap muka antara pendidik dengan peserta didik, baik di kelas maupun di luar kelas. Perubahan dimaksud adalah proses pembelajaran secara konvensional kepada proses pembelajaran yang variatif dengan penggunaan berbagai macam media teknologi informasi ${ }^{1}$. Perubahan pendekatan pembelajaran dari teacher center ke student center ini menjadikan peserta didik dapat belajar secara aktif, inovatif dan kreatif. Sehingga sumber belajar bukan lagi hanya pendidik tapi peserta didik dapat belajar dari berbagai sumber seperti media teknologi informasi yang semakin hari semakin canggih.

Pendidikan agama Kristen adalah salah satu mata pelajaran yang diajarkan di sekolah mulai dari tingkat dasar sampai perguruan tinggi. Tuntutan terhadap bidang studi ini untuk membentuk moral dan karakter peserta didik sesuai dengan tujuan pendidikan nasional sangat diharapkan, tapi kenyataan tidak sesuai dengan harapan. Salah satu problem atau keluhan yang dihadapi sekolah termasuk guru agama Kristen adalah kurangnya minat peserta didik belajar agama Kristen. Mungkin bisa diakibatkan cara mengajar yang masih bersifat tradisional dengan gaya ceramahnya yang monoton sehingga membuat peserta didik merasa bosan dan kurang menarik mengikuti mata pelajaran agama Kristen, apalagi dalam konteks sekarang ini yang sedang dalam kondisi pandemi covid-19. Penggunaan media teknologi informasi dalam kegiatan proses belajar mengajar merupakan solusi untuk membangkitkan minat belajar peserta didik. Salah satu peran pendidik dalam proses pembelajaran adalah sebagai fasilitator ${ }^{2}$, dalam hal ini seorang pendidik diharapkan mampu memfasilitasi kebutuhan belajar peserta didik. Sehingga seorang guru harus menguasai dan mampu menggunakan media teknologi informasi berbasis internet seperti penggunaan Komputer, HP dan media yang lain dengan baik.

Saat sekarang banyak sekolah-sekolah tidak dapat melaksanakan proses pembelajaran secara tatap muka, akibat merebaknya pandemi covid-19, maka dilaksanakanlah proses pembelajaran di luar kelas, jarak jauh secara online ${ }^{3}$. Berbagai jenis bentuk pembelajaran dilakukan untuk memenuhi kebutuhan peserta didik dan tercapainya tujuan pendidikan dimaksud seperti melalui Zoom, Google Classroom, WA dan lainnya. Tugas para pendidik (guru/dosen) adalah menyiapkan dan memfasilitasi proses pembelajaran berbasis internet secara daring dan online. Maka pendidik dituntut harus belajar dan mampu mempergunakan media teknologi informasi untuk memenuhi kebutuhan tersebut, yang dalam tulisan Rinto Hasiholan Hutapea dikatakan guru PAK harus kreatif dalam pengembangan media pembelajaran daring ${ }^{4}$.

\footnotetext{
${ }^{1}$ Johanes Waldes Hasugian, Strategi Belajar Mengajar Pendidikan Agama Kristen Yang Efektif (Prodi Teologi STT-SU, 2016).

${ }^{2}$ Johanes Waldes Hasugian, Menjadi Guru PAK Profesional Melalui Supervisi Pendidikan Agama Kristen, 2nd ed. (Medan: CV. Mitra, 2016).

${ }^{3}$ Albet Saragih and Johanes Waldes Hasugian, "Model Asuhan Keluarga Kristen Di Masa Pandemi Covid-19," Teruna Bhakti 3, no. 1 (2020): 1-11, http://stakterunabhakti.ac.id/ejournal/index.php/teruna/article/view/56.

${ }^{4}$ Rinto Hasiholan Hutapea, "Kreativitas Mengajar Guru Pendidikan Agama Kristen Di Masa Covid-19," Didaché: Journal of Christian Education 1, no. 1 (2020): 1-12, journal.sttsimpson.ac.id/index.php/DJCE.
} 


\section{Metode Penelitian}

Penelitian ini dilakukan dengan menggunakan metode kualitatif deskriptif, yaitu dengan menggunakan sumber informasi berdasarkan sumber literatur atau pustaka (library reserach). Adapun pemilihan metode ini adalah untuk menelusuri dan menemukan berbagai informasi berkenaan dengan pemanfaatan atau penggunaan media teknologi informasi dalam proses pembelajaran PAK di sekolah khususnya pada masa pandemi covid-19.

\section{Hasil dan Pembahasan}

\section{Pengertian Media Teknologi Informasi}

Bambang Warsita memberikan defenisi kata "media" secara harafiah, yang berasal dari bahasa Latin dan merupakan bentuk jamak dari kata medium yang artinya 'perantara' atau pengantar. Dengan demikian, media adalah perantara atau pengantar pesan dari pengirim ke penerima pesan". 5 Sementara itu, Oetomo menjelaskan bahwa:

Banyak batasan yang diberikan orang dengan media, antara lain menurut Association for Education and Communication Technology (AECH) yang membatasi media sebagai segala bentuk dan saluran yang digunakan orang untuk menyalurkan pesan atau informasi. Sementara itu, Asosiasi Pendidikan Nasional (National Education Association/NEA) bahwa media adalah bentuk-bentuk komunikasi baik cetak maupun audio visual serta peralatannya. ${ }^{6}$

Dengan mengutip pernyataan Gagne, Sadiman mengemukakan bahwa media adalah segala alat fisik yang dapat menyajikan pesan serta merangsang peserta didik untuk belajar" ${ }^{7}$. Pandangan tersebut sejalan dengan apa yang dikatakan oleh Arsyad, yang mendefinisikan medium (media) sebagai: "Teknologi untuk menyajikan, merekam, membagi, dan mendistribusikan simbol melalui rangsangan indera tertentu, disertai penstrukturan informasi" $"$. Kedua pendapat ini memiliki penekanan pada dua hal yang berbeda dimana pertama ditekankan kepada alat dan kedua menekankan kepada teknologi non fisik. Tergantung pemanfaatan media itu sendiri dalam kegunaannya.

Secara lebih khusus, Olson dalam Miarso mengemukakan bahwa media dalam proses belajar mengajar cenderung diartikan sebagai alat-alat grafis, photografis, atau elektronis untuk menangkap, memproses, dan menyusun kembali informasi visual atau verbal"". Pada pembahasan tentang media, istilah media pendidikan dan media pembelajaran pada beberapa literatur menunjukkan makna yang sama dan dapat digunakan secara bergantian. Sementara itu Briggs dalam Miarso mengemukakan bahwa media dalam dunia pendidikan adalah sarana untuk memberikan rangsangan bagi pelajar agar proses belajar terjadi ${ }^{10}$. Miarso menyatakan bahwa media pembelajaran adalah segala sesuatu yang digunakan untuk

\footnotetext{
${ }^{5}$ Bambang Warsita, Teknologi Pembelajaran (Jakarta: PT. Rieka Cipta, 2008).

${ }^{6}$ Budi Sutedjo Dharma Oetomo, E-Education: Konsep, Teknologi Dan Aplikasi Internet Pendidikan (Yogyakarta: CV. Andi Offset, 2007).

${ }^{7}$ Arief S. Sadiman, dkk, Media Pendidikan: Pengertian, Pengembangan Dan Pemanfaatannya (Jakarta: Raja Grafindo Persada, 1996).

${ }^{8}$ Azhar Arsyad, Media Pendidikan Suatu Pengantar (Bandung: Pusat Pelayanan dan Pengembangan Media Pendidikan, IKIP Bandung, 2004).

${ }^{9}$ Yusuf Hadi Minarso, Menyemai Benih Teknologi Pendidikan (Jakarta: Pustekkom Diknas dan Kencana, 2004).

${ }^{10}$ Ibid.
} 
menyalurkan pesan serta dapat merangsang pikiran, perasaan, perhatian, dan kemauan peserta didik sehingga dapat mendorong terjadinya proses belajar yang disengaja, bertujuan dan terkendali. ${ }^{11}$

Beberapa pandangan di atas, memberikan pemahaman bahwa apapun bentuk dan jenisnya media merupakan sarana atau alat yang dapat menyajikan atau mendistribusikan suatu pesan atau informasi baik secara visual atau verbal. Tujuannya adalah sarana untuk memberikan perangsangan bagi para pendengarnya, untuk lebih memahami informasiinformasi yang disampaikan secara lebih menarik.

\section{Media Teknologi Informasi}

Teknologi pada hakikatnya adalah alat untuk mendapatkan nilai tambah menghasilkan produk yang bermanfaat ${ }^{12}$. Sedangkan menurut Hariningsih, teknologi informasi meliputi segala hal yang berkaitan dengan proses, penggunaan sebagai alat bantu, manipulasi, dan pengelolaan informasi. Teknologi komunikasi merupakan segala hal yang berkaitan dengan penggunaan alat bantu untuk memproses dan mentransfer data dari perangkat yang satu ke lainnya". ${ }^{13}$ Karena itu, teknologi informasi dan komunikasi adalah suatu yang tidak terpisahkan yang mengandung pengertian luas tentang segala kegiatan yang terkait dengan pemrosesan, manipulasi, pengelolaan, dan transfer/pemindahan informasi antar media. Dengan kata lain, bahwa teknologi informasi disampaikan dalam bentuk komunikasi baik verbal maupun non verbal.

Munir memandang bahwa teknologi informasi dan komunikasi adalah berbagai aspek yang melibatkan teknologi, rekayasa dan teknik pengelolaan yang digunakan dalam pengendalian dan pemrosesan informasi serta penggunaannya, hubungan komputer dengan manusia dan hal yang berkaitan dengan sosial, ekonomi dan kebudayaan. ${ }^{14}$ Uno dan Lamatenggo mengemukakan bahwa teknologi informasi adalah suatu teknologi yang digunakan untuk mengolah data yang dimana pengolahan itu termasuk memproses, mendapatkan, menyusun, menyimpan, memanipulasi data dalam berbagai cara untuk menghasilkan informasi yang berkualitas, yaitu informasi yang relevan, akurat dan tepat waktu"15. Dengan demikian, dapat disebutkan bahwa media teknologi informasi merupakan sarana pendukung yang digunakan sebagai penyedia informasi yang telah dihimpun sebelumnya. Selain itu, media teknologi infirmasi dalam pendidikan adalah suatu peralatan lunak (software) yang digunakan sebagai perantara untuk menyampaikan pesan dan dapat merangsang pikiran, perasaan dan kemajuan (peserta didik) sehingga dapat mendorong dan membantu terjadinya proses belajar mengajar.

\section{Macam-Macam Media dan Produk Teknologi Informasi}

Teknologi Informasi mempunyai banyak macam jenisnya, dan disini akan dipaparkan beberapa macam bentuk teknologi informasi pembelajaran.

${ }^{11}$ Ibid.

${ }^{12}$ Munir, Tantangan Pendidikan Nasional (Jakarta: Depdiknas RI, 2009).

${ }^{13}$ S.P Hariningsih, Belajar E-Learning (Jakarta: Inti Media, 2005).

${ }^{14}$ Munir, Tantangan Pendidikan Nasional.

${ }^{15}$ Hamzah B. Uno and Nina Lamatenggo, Teknologi Komunikasi Dan Informasi Pembelajaran (Jakarta: Bumi Aksara, 2011). 
Laptop/ Notebook. Laptop/ Notebook adalah perangkat canggih yang fungsinya sama dengan komputer tetapi bentuknya praktis dapat dilihat dan dibawa kemana-mana karena bobotnya yang ringan, bentuknya yang ramping dan daya listriknya yang menggunakan baterai charger, sehingga bisa digunakan tanpa harus mencolokkan ke steker.

Deskbook. Deskbook adalah perangkat sejenis komputer dengan bentuknya yang jauh lebih praktis yaitu CPU menyatu dengan monitor sehingga mudah diletakkan di atas meja tanpa memakan banyak tempat. Namun, alat ini masih menggunakan sumber listrik steker karena belum dilengkapi baterai charger.

Personel Digital Assistant (PDA). PDA adalah perangkat sejenis komputer, tetapi bentuknya sangat mini sehingga dapat dimasukkan dalam saku. Walaupun begitu, fungsinya hampir sama dengan komputer pribadi yang dapat mengolah data.

Kamus Elektronik. Kamus elektronik adalah perangkat elektronil yang digunakan untuk menerjemahkan antar bahasa.

MP4 Player. MP4 Player adalah perangkat yang dapat digunakan sebagai media penyimpanan data sekaligus sebagai alat pemutar video, musik dan game.

MP3 Player. Hampir sama dengan MP4, MP3 Player adalah perangkat yang dapat menyimpan data hanya saja MP3 ini tidak dapat memutar video dan game, hanya dapat memutar musik dan mendengarkan radio.

Flasdisk. Flasdisk adalah media penyimpanan data portable yang berbentuk Universal Serial Bus. Ukurannya kecil dan bobotnya sanga ringan, tetapi dapat menyimpan data dalam jumlah besar.

Komputer. Komputer adalah perangkat berupa hardware dan software yang digunakan untuk membantu manusia dalam mengolah data menjadi informasi dan menyimpannya untuk ditampilkan di lain waktu. ${ }^{16}$

Media teknologi informasi tidak akan berguna tanpa produk dari pada teknologi infomasi tersebut, sebab media adalah prasarana informasi sedangkan produk teknologi adalah sarana informasi yang dipakai melalui media teknologi. Berikut ini beberapa produkproduk teknologi informasi sebagai berikut:

\section{Perangkat Keras (Hardware)}

Komputer. Perkembangan komputer sangat cepat, yang termasuk komputer antara lain: (1) Minicomputer, mainframe, (2) PC (Personal Computer), (3) Laptop/Notebook, (4) Palmtop, (5) PDA (Personal Digital Assistant).

Jaringan Komunikasi. Jaringan komunikasi adalah sebuah sistem yang mampu menghubungkan dan menggabungkan beberapa titik komunikasi menjadi satu kesatuan yang mampu berinteraksi antara satu dengan yang lainnya. Jaringan komunikasi meliputi:

ISDN (Integrated Service Digital Network) ISDN merupakan jaringan komunikasi khusus yang menggunakan jaringan telepon yang tidak hanya merespon suara, tetapi juga mampu menangani penyimpanan data berupa teks, gambar, video, faksimili dan lain-lain.

Elephone. Telepon adalah alat komunikasi dua arah yang memungkinkan untuk bercakap-cakap tanpa batasan jarak.

\footnotetext{
${ }^{16}$ Oetomo, E-Education: Konsep, Teknologi Dan Aplikasi Internet Pendidikan.
} 
Facsimile. Facsimile merupakan alat yang mampu mengirimkan dokumen secara sama persis melalui jaringan telepon.

Fiber Optic. Fiber Optic merupakan jaringan komunikasi yang mampu mentransmisikan data dalam frekuensi tinggi. Komunikasi tidak dengan perantara kawat tembaga tetapi menggunakan cahaya sebagai pengantar data.

Leased Line. Leased Line merupakan jaringan tetap yang menghubungkan dua tempat atau lebih. Jaringan ini dikenal juga dengan privat line.

Wireless. Wireless adalah jaringan komunikasi nirkabel. Jaringan ini menggunakan alat pemancar, penguat, dan penerima gelombang yang berisi data tersebut.

Jaringan komunikasi dengan satelit. Jaringan komunikasi dengan satelit meliputi: TV dan Radio, Komunikasi Seluler dan VSAT.

Net tools (alat komunikasi jaringan). Contoh Net tools (alat komunikasi jaringan) antara lain: server, client, router, modem (modulator/demodulator), repeater, dan bridge.

Perangkat Lunak (Software), diantaranya: DSS (Decision Support System), ECommerce, E-Banking, GIS (Geographical Information System), Expert System (Sistem Pakar), OA (Office Automation), Internet. ${ }^{17}$

Penulis melihat pada umumnya, pemakaian media teknologi, kebanyakan memanfaatkan produk internet untuk menemukan, mencari dan mengunduh setiap bentuk kebutuhan informasi melalui internet. Dengan kata lain, bahwa melalui jaringan internet, segala sesuatunya dihubungkan dengan cepat. Internet adalah sebuah jaringan komputer yang sangat besar yang terdiri dari jaringan-jaringan kecil yang saling terhubung yang menjangkau seluruh dunia ${ }^{18}$.

Sejalan dengan pandangan tersebut, Kadir dalam Uno dan Lamatenggo mengemukakan bahwa internet adalah sebuah jaringan computer yang menghubungkan jutaan komputer yang tersebar di seluruh dunia"19. Wiliam dalam Uno dan Lamatenggo mengemukakan bahwa internet adalah kumpulan jaringan komputer sehingga pemakai dapat berbagi informasi dengan sumber-sumber yang lebih luas" ${ }^{20}$. Jadi, teknologi informasi pembelajaran di sekolah lebih banyak berbasis internet merupakan suatu teknologi untuk mengolah data yang di dalamnya dapat memproses, menyusun, dan menyimpan data, dan teknologi ini tersambung dengan jaringan-jaringan komputer sehingga dapat digunakan sebagai sumber belajar untuk proses belajar mengajar.

\section{Manfaat Penggunaan Teknologi Informasi Pembelajaran}

Manfaat yang dapat diberikan melalui aplikasi teknologi informasi ini adalah mendapatkan informasi berbagai hal seperti kesehatan, hobi, rekreasi dan hal-hal yang bersifat rohani. Selanjutnya untuk profesi seperti sains, teknologi, perdagangan, berita bisnis, dan asosiasi profesi. Sarana kerjasama antara pribadi atau kelompok yang satu dengan pribadi atau kelompok yang lainnya tanpa mengenal batas jarak dan waktu, negara, ras, kelas ekonomi, ideologi atau faktor lainnya yang dapat menghambat bertukar pikiran.

\footnotetext{
${ }^{17}$ Hariningsih, Belajar E-Learning.

${ }^{18}$ Oetomo, E-Education: Konsep, Teknologi Dan Aplikasi Internet Pendidikan.

${ }^{19}$ Uno and Lamatenggo, Teknologi Komunikasi Dan Informasi Pembelajaran.

${ }^{20}$ Ibid.
} 
Globalisasi telah memicu kecenderungan pergeseran dalam dunia pendidikan dari pendidikan tatap muka yang konvensional ke arah pendidikan yang lebih terbuka dan dapat diakses oleh siapapun juga yang memerlukan tanpa melihat perbedaan usia, jenjang pendidikan, dan status social lainnya, tapi akan lebih ditentukan oleh jaringan informasi yang memungkinkan berinteraksi dan kolaborasi, antara satu dengan lainnya. Manfaat yang diperoleh oleh guru, yaitu lebih mudah melakukan pemutakhiran bahan-bahan belajar yang menjadi tanggung jawabnya sesuai dengan tuntutan perkembangan kelimuan, mengembangkan diri atau melakukan penelitian guna meningkatkan wawasannya karena waktu luang yang dimiliki relatif banyak, mengontrol kebiasaan belajar peserta didik. Bahkan guru juga dapat mengetahui kapan peserta didiknya belajar, topik apa yang dipelajari berapa lama suatu topik dipelajari serta berapa kali topik tertentu dipelajari ulang, hal ini bisa diketahui melalui penggunaan media belajar zoom, google classroom, WA dan media lainnya. Mengecek peserta didik telah mengerjakan soal-soal latihan setelah mempelajari topik tertentu. Memeriksa jawaban peserta didik dan memberitahukan hasilnya kepada peserta didik. Mendorong menumbuhkan sikap kerja sama antara guru dengan guru dan guru dengan peserta didik dalam memecahkan masalah pembelajaran.

Berdasarkan uraian di atas, berkenaan dengan pemanfaatan media teknologi informasi, kita dapat melihat bahwa hal tersebut sangat berhubungan dengan guru PAK dan perannya dalam pengajaran, yaitu dalam memanfaatkan teknologi informasi untuk memperbaiki mutu pembelajaran, sekaligus dengan tujuan untuk meningkatkan minat belajar pendidikan agama Kristen peserta didik di sekolah. Oleh karena itu, terdapat tiga hal yang harus diwujudkan yaitu: pertama, Peserta didik dan guru harus memiliki akses kepada teknologi digital dan internet dalam kelas, sekolah, dan lembaga pendidikan guru. Kedua, Harus tersedia materi yang berkualitas, bermakna, dan dukungan kultural bagi peserta didik dan guru. Ketiga, Guru PAK harus memiliki wawasan, pengetahuan dan keterampilan dalam menggunakan alat-alat dan sumber-sumber digital untuk membantu peserta didik agar mencapai standar akademik. $^{21}$

Oleh karena itu, dengan pesatnya perkembangan teknologi informasi, maka telah terjadi pergeseran pandangan tentang pembelajaran baik di kelas maupun di luar kelas. Hal itu telah mengubah peran guru dan peserta didik dalam pembelajaran. Peran guru telah berubah, yaitu pertama, sebagai penyampai pengetahuan, sumber utama informasi, ahli materi, dan sumber segala jawaban, menjadi sebagai fasilitator pembelajaran, pelatih, kolaborator, navigator pengetahuan, dan mitra belajar. Kedua, sebagai pengendali dan pengarah semua aspek pembelajaran, menjadi lebih banyak memberikan alternatif dan tanggung jawab kepada setiap peserta didik dalam proses pembelajaran. Sementara itu, peran peserta didik dalam pembelajaran telah mengalami perubahan, yaitu: pertama, Dari penerima informasi yang pasif menjadi partisipan aktif dalam proses pembelajaran. Kedua, Dari mengungkapkan kembali pengetahuan menjadi menghasilkan dan berbagai pengetahuan. Ketiga, Dari pembelajaran sebagai aktivitas individual menjadi pembelajaran berkolaboratif dengan peserta didik lain.

\footnotetext{
${ }^{21}$ Johanes Waldes Hasugian, "Menjadi Guru Pendidikan Agama Kristen Yang Berhasil,” Jurnal Teologi Didaskein 4, no. 2 (2016): 1-18.
} 


\section{Pembelajaran Pendidikan Agama Kristen melalui Berbagai Media}

Media pendidikan yang dapat digunakan mencakup media komunikasi seperti telepon, komputer, internet, e-mail, dsb, tidak terkecuali dalam pelaksanaan pendidikan agama Kristen. Interaksi antara guru dan peserta didik tidak hanya dilakukan melalui hubungan tatap muka tetapi juga dilakukan dengan menggunakan media-media tersebut ${ }^{22}$. Guru dapat memberikan layanan tanpa harus berhadapan langsung dengan peserta didik, apalagi di masa pandemi covid-19. Demikian pula peserta didik dapat memperoleh informasi dalam lingkup yang luas dari berbagai sumber melalui cyber space (ruang maya) dengan menggunakan komputer atau internet.

Hal yang paling mutakhir adalah berkembangnya apa yang disebut 'cyber teaching' (pengajaran maya), yaitu proses pengajaran yang dilakukan dengan menggunakan internet. Istilah lain yang makin poluper saat ini ialah e-learning yaitu satu model pembelajaran dengan menggunakan media teknologi komunikasi dan informasi khususnya internet. Rosenberg menjelaskan sebagaimana yang dikutip oleh Sutopo bahwa: e-learning merupakan satu penggunaan teknologi internet dalam penyampaian pembelajaran dalam jangkauan luas yang belandaskan tiga kriteria yaitu: e-learning berfungsi untuk menguba, menyimpan dan menyalurkan serta membagikan informasi, teknologi internet digunakan untuk tujuan pengiriman informasi melalui komputer, e-learning berfokus lebih luas dari paradigma pembelajaran tradisional. ${ }^{23}$

Saat ini, e-learning telah berkembang dalam berbagai model pembelajaran yang berbasis teknologi informasi, seperti: CBT (Computer Based Training), CBI (Computer Based Instruction), Distance Learning, Distance Education, CLE (Cybernetic Learning Environment), Desktop Videoconferencing, ILS (Integrated Learning Syatem), LCC (Learner-Cemterted Classroom), Teleconferencing, WBT (Web-Based Training), dsb. Satu bentuk produk teknologi informasi adalah internet yang berkembang pesat di penghujung abad 20 dan di ambang abad 21. Kehadirannya telah memberikan dampak yang cukup besar terhadap kehidupan umat manusia dalam berbagai aspek dan dimensi. Internet merupakan salah satu instrumen dalam era globalisasi yang telah menjadikan dunia ini menjadi transparan dan terhubungkan dengan sangat mudah dan cepat tanpa mengenal batas-batas kewilayahan atau kebangsaan.

Melalui internet setiap orang dapat mengakses ke dunia global untuk memperoleh informasi dalam berbagai bidang dan pada glirannya akan memberikan pengaruh dalam keseluruhan perilakunya. Dalam kurun waktu yang amat cepat beberapa dasawarsa terakhir telah terjadi revolusi internet di berbagai negara serta penggunaannya dalam berbagai bidang kehidupan. Keberadaan internet pada masa kini sudah merupakan satu kebutuhan pokok manusia modern dalam menghadapi berbagai tantangan perkembangan global, secara

\footnotetext{
22 Djoys Anneke Rantung and Fredik Melkias Boiliu, "Teknologi Dalam Pembelajaran Pendidikan Agama Kristen Yang Antisipatif Di Era Revolusi Indusri 4.0,” Jurnal Shanan 4, no. 1 (2020): 93-107, http://ejournal.uki.ac.id/index.php/shan/article/view/1770.

${ }^{23}$ Ariesto Hadi Sutopo, Teknologi Informasi Dan Komunikasi Dalam Pendidikan (Yogyakarta: Graha Ilmu, 2012).
} 
khusus pada masa pandemi covid-19 sekarang ini. ${ }^{24}$ Kondisi ini sudah tentu akan memberikan dampak terhadap corak dan pola-pola kehidupan umat manusia secara keseluruhan. Dalam kaitan ini, setiap orang atau bangsa yang ingin lestari dalam menghadapi tantangan global, perlu meningkatkan kualitas dirinya untuk beradaptasi dengan tuntutan yang berkembang. Teknologi informasi telah mengubah wajah pembelajaran yang berbeda dengan proses pembelajaran tradisional yang ditandai dengan interaksi tatap muka antara guru dengan peserta didik baik di kelas maupun di luar kelas.

\section{Blended Learning sebagai Alternatif Model Pembelajaran dalam PAK}

Dengan adanya perkembangan teknologi informasi dalam bidang pendidikan, maka pada saat ini sudah dimungkinkan untuk diadakan belajar jarak jauh dengan menggunakan media internet untuk menghubungkan antara peserta didik dengan gurunya, melihat nilai peserta didik secara online, mengecek keuangan, melihat jadwal pelajaran, mengirimkan berkas tugas yang diberikan guru dan sebagainya, semuanya itu sudah dapat dilakukan. Demikian juga dalam pelaksanaan pembelajaran pendidikan agama Kristen di dalam kelas. Sistem teknologi informasi ini, pengaturan dan pelaksanaannya dapat disesuaikan dengan kebutuhan, tanpa harus keluar dari tujuan pelaksanaan pendidikan agama Kristen itu sendiri.

Beberapa prinsip-prinsip penerapan e-pedagogy dalam mengaplikasikan media teknologi informasi ini dalam proses belajar mengajar PAK di sekolah dapat berupa: modul materi ajar yang telah disiapkan oleh guru, dapat diterima oleh peserta didik, sebelum materi itu diajar, sehingga pada saat tatap muka di dalam kelas, peserta didik sudah siap dengan segala macam tanggapan dan pertanyaan. Kemudian, juga dapat dilakukan dalam hal pelaksanaan tugas. Tugas dapat dikumpulkan secara online, sehingga memudahkan bagi semua pihak dalam melaksanakan tugasnya, menghemat waktu dan biasa serta tenaga. Demikian juga dalam pengaturan dan informasi jadwal doa, ibadah dan lainnya. Jika menggunakan dan memanfaatkan perrkembangan teknologi tersebut, semua dapat dilakukan dengan baik.

Faktor utama dalam distance learning yang selama ini dianggap masalah adalah tidak adanya interaksi antara guru dan peserta didik. Namun demikian, dengan media internet sangat dimungkinkan untuk melakukan interaksi antara guru dan peserta didik baik dalam bentuk real time atau tidak. Dalam bentuk realtime dapat dilakukan misalnya dalam suatu chat room, interaksi langsung dengan real audio atau real video, dan online meeting. Interaksi yang tidak realtime bisa dilakukan dengan mailing list, discussiongroup, newsgroup, dan bulletin board.

Menurut penulis, pembelajaran konvensional tidak lagi sepenuhnya menjadi andalan, namun di tengah kemajuan teknologi saat ini diperlukan variasi metode yang lebih memberikan kesempatan untuk belajar dengan memanfaatkan aneka sumber, tidak hanya dari man power seperti halnya guru. Pembelajaran yang dibutuhkan adalah dengan memanfaatkan unsur teknologi informasi, dengan tidak meninggalkan pola bimbingan langsung dari pengajar dan pemanfaatan sumber belajar lebih luas. Konsep ini sering juga

${ }^{24}$ Susanto Dwiraharjo, "Konstruksi Teologis Gereja Digital: Sebuah Refleksi Biblis Ibadah Online Di Masa Pandemi Covid-19," EPIGRAPHE: Jurnal Teologi dan Pelayanan Kristiani 4, no. 1 (2020): 1-17, http://www.stttorsina.ac.id/jurnal/index.php/epigraphe/article/view/145. 
diistilahkan dengan blended learning yaitu perpaduan antara pembelajaran konvensional di dalam kelas (tatap muka guru dan peserta didik) dengan pembelajaran e-learning berbasis web (online).

Ada beberapa hal yang perlu diperhatikan sebelum guru PAK memilih internet sebagai media teknologi informasi untuk kegiatan pembelajaran. Uraian Hartanto dan Purbo membantu kita untuk memahami faktor-faktornya sebagai dasar pertimbangan dalam pemilihan internet untuk kepentingan pengajarna di sekolah, yaitu:

Pertama, Analisis kebutuhan (need analysis). Dalam tahapan awal, satu hal yang perlu dipertimbangkan adalah apakah memang memerlukan e-learning. Pertanyaan ini tidak dapat dijawab dengan perkiraan atau dijawab berdasarkan atas saran orang lain. Setiap lembaga menentukan teknologi pembelajaran sendiri yang berbeda satu sama lain. Untuk itu perlu diadakan analisis kebutuhan atau need analysis yang mencakup studi kelayakan baik secara teknis, ekonomis, maupun sosial. Kedua, Rancangan pembelajaran yang berisi tentang isi pelajaran, topik, satuan kredit, bahan ajar/kurikulum. Ketiga, Evaluasi yaitu sebelum program dimulai, ada baiknya ujicobakan dengan mengambil beberapa sampel orang yang dimintai tolong untuk ikut mengevaluasi. Selanjutnya, hal lain yang harus diperhatikan adalah masalah yang sering dihadapi yaitu: pertama, akses dalam pemanfaatan e-learning, misalnya ketersediaan jaringan internet, listrik, telepon dan infrastruktur yang lain yang relevan. Kedua, ketersediaan software. mengusahakan agar software yang dipakai dapat terjangkau biayanya. Ketiga, dampaknya terhadap kurikulum yang ada. Keempat, skill and knowledge. ${ }^{25}$

Oleh karena itu perlu diciptakan bagaimana semuanya mempunyai sikap yang positif terhadap media teknologi informasi dan perangkatnya sehingga penggunaan teknologi baru bisa mempercepat pembangunan.

\section{Teknologi Informasi dalam Pembelajaran PAK di Masa Pandemi Covid-19}

Menyadari bahwa media teknologi informasi seperti internet dapat ditemukan berbagai informasi yang mudah diakses, kapan saja dan di mana saja, maka pemanfaatan media teknologi informasi menjadi suatu kebutuhan, khusunya dalam pembelajaran PAK. Bukan itu saja, pengguna media teknologi informasi bisa berkomunikasi dengan pihak lain dengan cara yang sangat mudah melalui teknik e-moderating yang tersedia di internet. Menurut Kamarga pada dasarnya ada empat hal yang perlu disiapkan sebelum pemanfaatan media teknologi informasi dalam hal belajar e-learning yaitu: pertama, melakukan penyesuaian kurikulum yang sifatnya holistik, berbasis kompetensi dan diintegrasikan dengan kebutuhan atau konteks masa kini. Kedua, dalam rangka pencapaian dasar kompetensi komputer digunakan dengan tujuan variasi mengajar. Ketiga, memanfaatkan teknologi, dalam hal ini komputer untuk melakukan penilaian. Keempat, Menyediakan materi pembelajaran seperti buku, komputer, multimedia, studio, dll yang memadai. ${ }^{26}$

${ }^{25}$ A.A Hartanto and O.W Purbo, Teknologi E-Learning Berbasis Php Dan Mysql (Jakarta: Elex Media Komputindo, 2002).

${ }^{26}$ Hanny Kamarga, Belajar Sejarah Melalui E-Learning: Alternatif Mengakses Sumber Informasi Kesejarahan (Jakarta: Inti Media, 2002). 
Soekartawi mengemukakan bahwa dengan memanfaatkan media teknologi informasi dalam proses belajar mengajar, baik secara langsung maupun tidak langsung, terdapat beberapa kelebihan, bahwa pemanfaatan media teknologi informasi dalam proses belajar mengajar menyebabkan komunikasi antar peserta didik dan guru menjadi lancar, penggunakan bahan ajar yang lengkap karena sistem online sehingga peserta didik dapat me-review bahan ajar yang ia terima kembali. Kemudian hal yang paling penting adalah peran peserta didik dari pasif menjadi aktif. Keadaan inilah yang dapat meningkatkan minat belajar peserta didik, karena tidak membosankan, lebih menarik. Sehingga, proses ini dapat disebut sebagai bermain sambil belajar. Disamping itu, pemanfaatan internet untuk pembelajaran atau media teknologi informasi melalui e-learning juga tidak terlepas dari berbagai kekurangan. Beberapa kelemahan yang dapat dirasakan dalam pemanfaatan teknologi informasi dalam proses belajar mengajar adalah interaksi guru dan peserta didik menjadi berkurang, terdapat kecenderungan mengabaikan aspek akademik ataupun sosial, pembelajaran cenderung ke arah pelatihan bukan pendidikan, terjadi perubahan peran guru yang konvensional menjadi menguasai teknik pembelajaran yang menggunakan internet, keterbatasan fasilitas internet, dan keterbatasan sumber daya manusia yang menguasa ataupun terampil di bidang internet dan jaringan komputer. ${ }^{27}$

Melalui pemanfaatan teknologi informasi, diharapkan materi ajar dapat diakses oleh siapa saja dan kapan saja terlebih saat sekarang, masa pandemi covid-19 sangat diharapkan penggunaan teknologi informasi ini. Akses terhadap materi ajar sebenarnya dapat diatur bila dikehendaki karena tersedia fasilitas pengaman. Misalnya, jika materi tidak mau diakses oleh orang lain dan hanya orang yang telah mendaftar saja yang bisa mengakses materi ajar tersebut. Namun, model ajar ini, adalah keterbatasan pihak sekolah untuk menyediakan komputer termasuk internet dalam proses pengajaran. Oleh karena itu, perlu ada aksi untuk menyiapkan institusi pendidikan (ready for learning), yaitu dengan cara melibatkan para guru dan departemen terkait, misalnya kementerian agama, kemendikbud, dan kementerian lainnya yang ada di wilayah masing-masing.

Melalui penggunaan media teknologi informasi setiap peserta didik akan terangsang untuk belajar maju berkelanjutan sesuai dengan potensi dan kecakapan yang dimilikinya. Pembelajaran dengan menggunakan teknologi informasi menuntut kreativitas dan kemandirian diri sehingga memungkinkan mengembangkan semua potensi yang dimilikinya. Dalam kaitan ini, guru memegang peran yang amat penting dan harus menguasai seluk beluk teknologi informasi dan yang lebih penting lagi adalah kemampuan memfasilitasi pembelajaran anak secara efektif. Peran guru sebagai pemberi informasi harus bergeser menjadi manajer pembelajaran dengan sejumlah peran-peran tertentu, karena guru bukan satu-satunya sumber informasi melainkan hanya salah satu sumber informasi.

Sebagai pelatih (coaches), guru harus memberikan peluang yang sebesar-besarnya bagi peserta didik untuk mengembangkan cara-cara pembelajarannya sendiri sesuai dengan kondisi masing-masing. Sebagai konselor, guru harus mampu menciptakan satu situasi interaksi belajar-mengajar, dimana peserta didik melakukan perilaku pembelajaran dalam

\footnotetext{
${ }^{27}$ Soekortawi, Prospek Pembelajaran Melalui Internet, Seminar Nasional "Teknologi Kependidikan" (Jakarta, 2002).
} 
suasana psikologis yang kondusif dan tidak ada jarak yang kaku dengan guru. Sebagai manajer pembelajaran, guru memiliki kemandirian dan otonomi yang seluas-luasnya dalam mengelola keseluruhan kegiatan belajar mengajar dengan mendinamiskan seluruh sumbersumber penunjang pembelajaran. Sebagai partisipan, guru tidak hanya berperilaku mengajar akan tetapi juga berperilaku belajar dari interaksinya dengan peserta didik.

Hal ini mengandung makna bahwa guru bukanlah satu-satunya sumber belajar bagi anak, akan tetapi ia sebagai fasilitator pembelajaran peserta didik. Sebagai pemimpin, diharapkan guru mampu menjadi seseorang yang mampu menggerakkan orang lain untuk mewujudkan perilaku menuju tujuan bersama. Kondisi saat sekarang, masa pandemi covid19 mengharuskan sistem pembelajaran dilakukan secara online melalui zoom, classroom, WA dan lainnya. Maka dengan penguasaan media teknologi informasi berbasis internet oleh peserta didik dan pendidik proses belajar mengajar tetap berjalan dengan baik. Sebagai seorang pendidik harus selalu kreatif dan inovatif menghasilkan berbagai karya yang akan digunakan untuk melaksanakan tugas-tugas profesionalnya.

\section{Kesimpulan}

Belajar adalah hak peserta didik dimasa aman maupun dimasa tidak aman dan mengajar adalah kewajiban guru/dosen dimasa sulit sekalipun seperti dimasa pandemi Covid-19. Namun hak dan kewajiban dari kedua belah pihak ini menjadi tidak teraktualisasikan secara normal karena kondisi yang tidak mendukung. Namun guru/dosen wajib tahu dan melaksanakan kewajibannya atas hak peserta didik dengan segenap daya dan kemampuannya sehingga pelaksanaan proses belajar mengajar tetap berjalan dengan baik. Tentang bagaimana cara melaksanakan proses belajar mengajar tersebut akan terpulang pada perminatan dan kebermanfaatan media tenologi yang digunakan oleh guru/dosen yang mengajarkan materi pendidikan agama Kristen. Penggunaan media teknologi informasi dalam kegiatan proses pembelajaran bukan hanya membangkitkan minat belajar peserta didik, tetapi juga sekaligus dapat menjawab kebutuhan belajar peserta didik dimasa pandemi Covid19. Oleh karena itu, para pendidik diharapkan tidak hanya mampu memfasilitasi kebutuhan belajar peserta didik tetapi harus menguasai dan mampu mempergunakan media teknologi informasi. Jangan sampai terjadi pelaksanaan proses belajar mengajar pendidikan agama Kristen berlangsung selama satu semester tetapi tidak ada perbaikan sama sekali pada ranah afektif, psikomotorik dan kognitif peserta didik, oleh karena pendidik tidak mampu memanfaatkan media teknologi informasi dalam pembelajaran pendidikan agama Kristen.

\section{Referensi}

Arsyad, Azhar. Media Pendidikan Suatu Pengantar. Bandung: Pusat Pelayanan dan Pengembangan Media Pendidikan, IKIP Bandung, 2004.

Dwiraharjo, Susanto. "Konstruksi Teologis Gereja Digital: Sebuah Refleksi Biblis Ibadah Online Di Masa Pandemi Covid-19.” EPIGRAPHE: Jurnal Teologi dan Pelayanan Kristiani 4, no. 1 (2020): 1-17. http://www.stttorsina.ac.id/jurnal/index.php/epigraphe/article/view/145.

Hariningsih, S.P. Belajar E-Learning. Jakarta: Inti Media, 2005.

Hartanto, A.A, and O.W Purbo. Teknologi E-Learning Berbasis Php Dan Mysql. Jakarta: Elex Media Komputindo, 2002. 
Hasugian, Johanes Waldes. Menjadi Guru PAK Profesional Melalui Supervisi Pendidikan Agama Kristen. 2nd ed. Medan: CV. Mitra, 2016.

_. "Menjadi Guru Pendidikan Agama Kristen Yang Berhasil." Jurnal Teologi Didaskein 4, no. 2 (2016): 1-18.

—. Strategi Belajar Mengajar Pendidikan Agama Kristen Yang Efektif. Prodi Teologi STT-SU, 2016.

Hutapea, Rinto Hasiholan. "Kreativitas Mengajar Guru Pendidikan Agama Kristen Di Masa Covid-19." Didaché: Journal of Christian Education 1, no. 1 (2020): 1-12. journal.sttsimpson.ac.id/index.php/DJCE.

Kamarga, Hanny. Belajar Sejarah Melalui E-Learning: Alternatif Mengakses Sumber Informasi Kesejarahan. Jakarta: Inti Media, 2002.

Minarso, Yusuf Hadi. Menyemai Benih Teknologi Pendidikan. Jakarta: Pustekkom Diknas dan Kencana, 2004.

Munir. Tantangan Pendidikan Nasional. Jakarta: Depdiknas RI, 2009.

Oetomo, Budi Sutedjo Dharma. E-Education: Konsep, Teknologi Dan Aplikasi Internet Pendidikan. Yogyakarta: CV. Andi Offset, 2007.

Rantung, Djoys Anneke, and Fredik Melkias Boiliu. “Teknologi Dalam Pembelajaran Pendidikan Agama Kristen Yang Antisipatif Di Era Revolusi Indusri 4.0." Jurnal Shanan 4, no. 1 (2020): 93-107. http://ejournal.uki.ac.id/index.php/shan/article/view/1770.

Sadiman, dkk, Arief S. Media Pendidikan: Pengertian, Pengembangan Dan Pemanfaatannya. Jakarta: Raja Grafindo Persada, 1996.

Saragih, Albet, and Johanes Waldes Hasugian. "Model Asuhan Keluarga Kristen Di Masa Pandemi Covid-19." Teruna Bhakti 3, no. 1 (2020): 1-11. http://stakterunabhakti.ac.id/e-journal/index.php/teruna/article/view/56.

Soekortawi. Prospek Pembelajaran Melalui Internet. Seminar Nasional "Teknologi Kependidikan." Jakarta, 2002.

Sutopo, Ariesto Hadi. Teknologi Informasi Dan Komunikasi Dalam Pendidikan. Yogyakarta: Graha Ilmu, 2012.

Uno, Hamzah B., and Nina Lamatenggo. Teknologi Komunikasi Dan Informasi Pembelajaran. Jakarta: Bumi Aksara, 2011.

Warsita, Bambang. Teknologi Pembelajaran. Jakarta: PT. Rieka Cipta, 2008. 